\title{
Strengthening Innovation Capacity through Different Types of Innovation Cultures

\author{
Jens-Uwe Meyer
}

\author{
"There are two kinds of adventurers: those who go truly hoping" \\ to find adventure and those who go secretly hoping they won't. \\ William Least Heat-Moon (Trogdon) \\ Travel writer and historian
}

\begin{abstract}
In times of increased market dynamics, companies must be capable of initiating and implementing innovation projects that vary greatly in type, speed, and degree of innovation. Many companies do not succeed. This article introduces Innolytics, an innovation management tool that allows companies to successfully face this challenge by analyzing their innovation culture and managing its development in the right direction. Analyzing empirical data from 200 staff members employed by German, Austrian, and Swiss companies using exploratory factor analysis, four types of innovation cultures were identified, each of which foster a different degree of organizational creativity. Proactive innovators (21\%) promote organizational creativity at a high level and across all categories. Strategic innovators (26\%) foster innovation by focusing on their strategy and their value system. Innovative optimizers (36\%) promote more adaptive levels whereas operational innovators (16\%) promote low levels of organizational creativity. Each type enables a company or a business unit to manage different degrees of innovation projects. The Innolytics tool introduced and described in this article will enable companies to better meet the challenges of rapidly changing markets.
\end{abstract}

\section{Introduction}

In dynamic markets, companies must manage a greater variety and a higher speed of innovations (Bjork, 2012). In the course of this effort, the different requirements for processes and abilities can quickly overstrain an organization's capacities (Benner \& Tushman, 2002). The current understanding of innovation management is characterized by process-oriented approaches (cf. Cooper, 1994; Cooper \& Kleinschmidt, 2001; Drucker, 1985) that focus on the establishment of innovation processes and the definition of roles as well as the establishment of key performance indicators (Cooper \& Kleinschmidt 1996, 2001). These approaches nevertheless demonstrate their limits in dynamic market environments.

Processes gain great importance when managing complex projects with a diversity of participants, such as the development of innovative technologies (Cooper, 2014; Högman \& Johannesson, 2013). Structured routines render advantages in terms of effectiveness but may hinder the development of something new (Junarsin, 2009). The strength of innovation processes appears to be in the ability to manage the innovation routine. Such a strategy of slow incremental change can be absolutely promising provided that the environment is stable or changes slowly (Tushman \& O'Reilly III, 1996). Nevertheless, this strategy is not always the most productive approach to meeting the demands of dynamic markets because innovation is not necessarily a linear process (Rickards, 1996). The farther a project strays from this routine and the higher its degree of uncertainty, the greater the demand is for more encompassing instruments that promote more far-reaching forms of innovation.

\section{Background}

Numerous authors describe the influence of the innovation culture on the innovative capacity of companies and company units (e.g., Ekvall, 2006; Lin \& Liu, 2012; 


\section{Strengthening Innovation Capacity through Different Types of Innovation Cultures}

Jens-Uwe Meyer

Naranjo et al., 2010). Category systems that outline the supporting framework conditions for creativity and innovation have been developed over recent years (e.g., Amabile et al., 1996; Khandwalla \& Mehta, 2004; Robinson \& Stern, 1997). These works assume that a company possesses an innovation culture to either a greater or lesser degree and that either a higher or lower innovative capacity can be derived from it (Dobni, 2008; Martins \& Terblanche, 2003).

Nevertheless, different types of innovations require different framework conditions (Junarsin, 2009; Leifer et al., 2000). According to Ekvall (2006), different degrees in organizational creativity are required for the achievement of different innovation goals. And, according to Tushman and O'Reilly (1996), different cultures that promote different degrees of creativity can exist in a single company. But, current research does not provide a systematic and sufficiently deep understanding of the various cultural conditions that foster different levels of creativity as a prerequisite for being able to manage different degrees of innovation in highly dynamic markets. The purpose of this article is to develop an empiricallybased comprehensive model in order to close this gap. For this purpose, the following hypotheses are established on the basis of a literature analysis:

Hypothesis 1: There are several degrees of organizational creativity. Each degree promotes a specific quality, scope, and radicality of innovation.

Hypothesis 2: Organizational units with different degrees of organizational creativity can be determined on the basis of characteristics and can be summarized into innovation types.

Hypothesis 3: Through the establishment of a management model based on types of innovation, companies can increase their ability to simultaneously develop different levels of innovation at varying speeds.

\section{Theoretical foundations and classification}

Up to the early 1990s, research had not yet provided broadly based scientific frameworks that explain the relationship between the work environment and creative achievements of staff members (Amabile, 1988; Woodman et al., 1993). A new research direction has since emerged as the field of organizational creativity that focuses less on the creative performance of an individual, but more so on the creative performance of an organization (e.g., Puccio \& Cabra, 2010; Zhou \& Shalley, 2008).
The number of studies on the subject of creativity has been continually accelerating over recent years (Runco \& Albert, 2010). Kozbelt, Beghetto, and Runco (2010) provide a comparative review of creativity theories and divide them into 10 categories. This work is a convergence of psychometric theories, typological theories, and system theories. Psychometric theories are based on the assumption that creativity can be measured using criteria (Kozbelt et al., 2010). Typological theories assume that there are different types of creative individuals and working styles (Kirton, 1976, 1989; Kozbelt, 2008; Martinsen, 1995). System theories are based on the assumption that creativity can be influenced by the system surrounding it (Kozbelt et al., 2010).

This article examines the question of how companies and company units can influence their innovative capacity at a system level by developing typologies of organizational creativity with the support of psychometric techniques.

\section{Definitions}

\section{Individual creativity}

The foundational element in this article is Amabile's (1996) componential model, which includes three major components of creativity: expertise, creative thinking, and intrinsic task motivation. This definition of creativity may be limited because the level of creative efficiency appears to be additionally influenced by specific character traits:

- Independence, independent judgment, autonomy (Amabile, 1996; Barron \& Harrington, 1981; Roth, 2001)

- Self-discipline or self-direction, highly achievementmotivated, perseverance in face of frustration, high energy (Amabile, 1996; Csikszentmihalyi, 2006; Kaufman \& Sternberg, 2006; Roth, 2001)

- Orientation toward taking risks (Amabile, 1996; Farson \& Keyes, 2002)

- Preference toward breaking the rules (Csikszentmihalyi, 2006)

- Largely unconcerned with regard to social acceptance (Amabile, 1996)

- Self-confidence (or self-efficacy) (Barron \& Harrington, 1981; Hill et al., 2008; Prabhu et al., 2008) 


\section{Strengthening Innovation Capacity through Different Types of Innovation Cultures}

Jens-Uwe Meyer

For the purposes of this research objective, an expansion is made on Amabile's consideration of the relationship between creativity and intelligence (Amabile, 1996; Sternberg, 1996). According to Roth (2001), high creativity requires an above-average, particularly linguistic, intelligence. The concept of creative intelligence is applied within the literature (e.g., Buzan, 2001; CarrRuffino, 2001; Dewey et al., 2011). This intelligence may determine the degree of creative efficiency that moves between moderately creative achievements (Amabile, 1996) and truly creative breakthroughs (Feist, 2010).

Within the scope of this research project, individual creative potential is defined as a collection of creative abilities and character traits that enable achievements that are considered in a defined social context as new and useful and that the degree and the area of these creative achievements are strongly influenced by creative intelligence and individual expertise (Figure 1).

\section{Definition of organizational creativity}

Many terms are explored in the literature regarding innovation and creativity at a systemic level: innovativeness, organizational creativity, entrepreneurial creativity and corporate creativity, creative climate, innovation supportive culture, and innovation culture (e.g., Dobni, 2008; Ekvall, 1996; Robinson \& Stern, 1997). A precise distinction between these terms is hardly possible on the basis of the present literature. The concept of innovation culture is defined within the scope of this article as the social environment that enables staff members to develop ideas and implement innovations. The concept of organizational creativity consists of two abilities: i) the ability to create this social environment as well as ii) the ability to utilize and exploit the resulting individual creativity of staff members.

\section{Design and Methodology}

For the analysis of the factors that promote organizational creativity referred to in the literature, authors have been selected who have followed the approach of listing all of the relevant factors and designating the factors that can be traceable and fully categorized:

- KEYS (Amabile et al., 1996)

- Six Factors Promoting Corporate Creativity (Robinson \& Stern, 1997)

- Culture and Climate for Innovation (Ahmed, 1998)

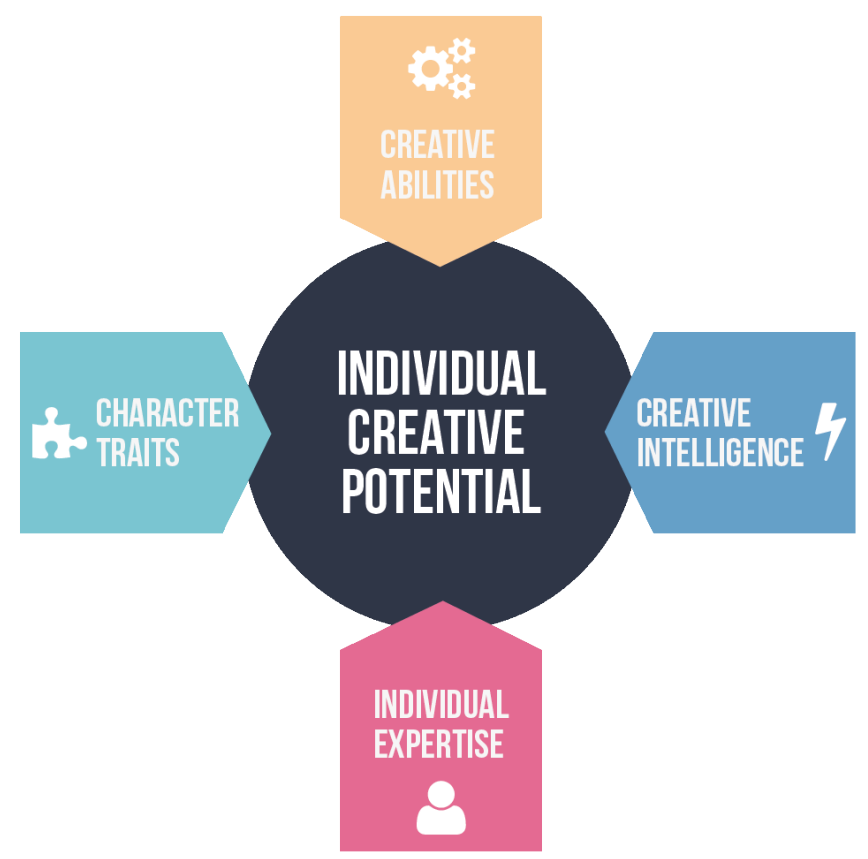

Figure 1. Individual creative potential and its influences

- Design of Corporate Creativity (Khandwalla \& Mehta, 2004)

- Model of Engagement in Creative Action (Unsworth \& Clegg, 2010)

- Key Issues Around Creating a Culture for Design, Creativity, and Innovation (von Stamm, 2005)

- Working Climate and Creativity (Ekvall \& TangebergAndersson, 1986)

- The Creativity Audit (Rickards \& Bessant, 1980)

- Measuring the Perceived Support for Innovation in Organizations (Siegel \& Kaemmerer, 1978)

- Organizational Creativity and Innovation (van Gundy, 1987)

- Needed Research in Creativity for Business and Industry Applications (Basadur, 1987)

- Exploratory Study for Creative Climate (Cabra et al., 2005)

- Measuring Climate for Work Group Innovation (Anderson \& West, 1998) 


\section{Strengthening Innovation Capacity through Different Types of Innovation Cultures}

\section{Jens-Uwe Meyer}

- Characteristics of an Organizational Environment Which Stimulates and Inhibits Creativity (Soriano de Alencar \& Bruno-Faria, 1997)

The 14 models include a total of 110 main categories some of which are further divided into subcategories by the authors. These categories have been grouped into clusters applying Amabile's line of thought, after which the generation and development of ideas can be supported at multiple levels of an organization (Amabile et al., 1996). For classification purposes, Kromey's (2002) principle of operational interpretation was applied:

1. The organizational level includes factors of overriding importance that affect the entire organization or organizational unit.

2. The management level includes factors that can be directly influenced by the supervisor of an employee, such as the promotion of ideas by superiors.

3. On the employee level, creativity can be promoted in relation to the tasks and projects employees and teams are working on.

4. The level of the work environment includes factors that are perceived and interpreted by individuals in their personal working environment.

These four levels were associated with the 110 categories designated by the authors above as main categories. The categories were then grouped into the four levels with ten new categories and a total of 48 newly created items (Table 1).

A questionnaire was developed for the survey, and the collected data were coded on a scale from 1 to 6 . After performing the factor analysis, the data were re-coded for clarity: values 1 to 3 were given the values -3 to -1 and the values of 4 to 6 were given the values 1 to 3 . Incomplete datasets were removed from the analysis. All items were weighted equally. With the help of this questionnaire, nearly 200 staff members responsible for innovation in companies from Germany, Austria, and Switzerland were questioned as to the extent to which the characteristic features listed in Table 1 promote organizational creativity in their scope of action.

The base population from which the sample drawn is formed companies that are referred to as "innovationactive" by the Center for European Economic Research
(Rammer et al., 2011), a group that represents nearly $57 \%$ of all companies. The surveys were sent to staff members of these companies who deal with innovation due to their job description (e.g., idea manager, innovation manager, business development, research and development) or for another reason.

The survey fulfills the requirements of specific representativity (Moosbrugger \& Kelava, 2012) as well as the quality criteria for objectivity, reliability, and validity.

Thirty-eight percent of the survey respondents are employed in companies that have between 51 and 1,000 staff members, $32 \%$ are in companies between 1,000 and 10,000 staff members, and $30 \%$ are employed in companies with more than 10,000 staff members. The majority $(67 \%)$ is directly responsible for innovation. Fourteen percent of the interviewees belong to the management or the boards of directors. Nineteen percent come from the marketing and public relations (8\%) departments, distribution (4\%), product management (5\%), or production (4\%). Nearly two-thirds of the interviewees are executives.

To clarify the primary objective of this research project - to determine the extent to which different degrees of organizational creativity can be defined - the underlying data material has been analyzed with the aid of an exploratory factor analysis as a hypothesis-generating process (Moosbrugger \& Schermelleh-Engel, 2012; Noack, 2007).

\section{Findings}

The results of the factor analysis show that there is a close relationship between the individual categories. Patterns could be found in the collected datasets. Respondents who, for example, evaluated their communication structures as being highly supportive of innovation almost always assessed their working climate and their risk culture as being equally supportive of innovation. There was also a strong correlation on the negative scale: respondents who evaluated their communication structures as being obstructive to innovation almost always assessed their working climate and their risk culture as being equally obstructive to innovation.

In evaluating the results of the exploratory factor analysis, four types of clusters were determined (Table 2). Their specific attributes, as evaluated on a scale from 1 to 6 , can be described in the following way: 


\section{Strengthening Innovation Capacity through Different Types of Innovation Cultures}

\section{Jens-Uwe Meyer}

Table 1. Model levels, categories, and items (continued on next page...)

\begin{tabular}{|c|c|c|}
\hline Level & Category & Items and Descriptions \\
\hline \multirow[t]{14}{*}{ Organization } & Strategy & The goal formulated by the top management team to strive for and promote innovations. \\
\hline & & $\begin{array}{l}\text { 1. Future strategy: Offensive, future-oriented strategy from which innovation requirements are } \\
\text { derived. }\end{array}$ \\
\hline & & 2. Innovation awareness: The awareness of the need for innovation. \\
\hline & & 3. Innovation aspiration: The aspiration to implement breakthrough innovations. \\
\hline & & $\begin{array}{l}\text { 4. Engagement of the top management: The degree to which the top managers develop their own } \\
\text { innovation activities. }\end{array}$ \\
\hline & & $\begin{array}{l}\text { 5. Sustainability: The sense that the innovation strategy over a long period of time is a } \\
\text { determining factor. }\end{array}$ \\
\hline & & $\begin{array}{l}\text { 6. Strategy communication: The magnitude to which the strategy is communicated and develops } \\
\text { a leading influence. }\end{array}$ \\
\hline & Values & Overriding factors: convictions and values. \\
\hline & & 1. Own responsibility: The sense of being personally responsible for innovation. \\
\hline & & $\begin{array}{l}\text { 2. Acceptance of contradictions: To manage the attitude in spite of possibly contradicting } \\
\text { information. }\end{array}$ \\
\hline & & 3. Lived philosophy: The magnitude to which innovators show a personal conviction. \\
\hline & & $\begin{array}{l}\text { 4. Value of creativity: The degree to which new ideas as well as creative thinking and action are } \\
\text { valued. }\end{array}$ \\
\hline & & $\begin{array}{l}\text { 5. Courage for radical ideas: The magnitude to which existing views are questioned and radical } \\
\text { ideas are recognized. }\end{array}$ \\
\hline & & $\begin{array}{l}\text { 6. Readiness for change: The degree to which a readiness exists to accept changes concerning the } \\
\text { structures and the scope of one's own duties. }\end{array}$ \\
\hline
\end{tabular}

Management Structures Creation of management structures with which creativity can be promoted.

1. Hierarchies: Permeability of hierarchy levels in the company.

2. Management structures and organization structures: Innovation-promoting management structures and organizational structures.

3. Control avoidance: The possibility to work around the rules if required.

4. Decisive speed: Speed of the decision-making processes.

5. Creativity-promoting practices and processes: Practices and processes that actively promote creativity and innovation.

\begin{tabular}{|c|c|}
\hline \multirow[t]{6}{*}{ Style } & A management style that promotes creativity and innovation. \\
\hline & $\begin{array}{l}\text { 1. Innovation goals: The measure to which concrete innovation goals are defined for ind } \\
\text { staff members. }\end{array}$ \\
\hline & $\begin{array}{l}\text { 2. Active promotion: The degree to which executives actively promote creative ideas and } \\
\text { innovation projects. }\end{array}$ \\
\hline & 3. Stimuli: The magnitude to which executives expose staff members to stimulative influ \\
\hline & $\begin{array}{l}\text { 4. Encouragement: The encouragement of staff members to transcend the limits of what } \\
\text { currently feasible. }\end{array}$ \\
\hline & 5. Autonomy: The magnitude to which executives grant autonomy to their staff member \\
\hline \multirow[t]{6}{*}{ Resources } & The granting of resources. \\
\hline & 1. Temporal resources: The granting of time freedoms. \\
\hline & 2. Financial and material resources: The granting of money and materials. \\
\hline & 3. Internal synergies: The possibility to fall back on the resources of other departments. \\
\hline & 4. External resources: Inclusion of external resources. \\
\hline & 5. Training / tools: The possibility for training. \\
\hline
\end{tabular}




\section{Strengthening Innovation Capacity through Different Types of Innovation Cultures}

\section{Jens-Uwe Meyer}

Table 1. Model levels, categories, and items (...continued from previous page)

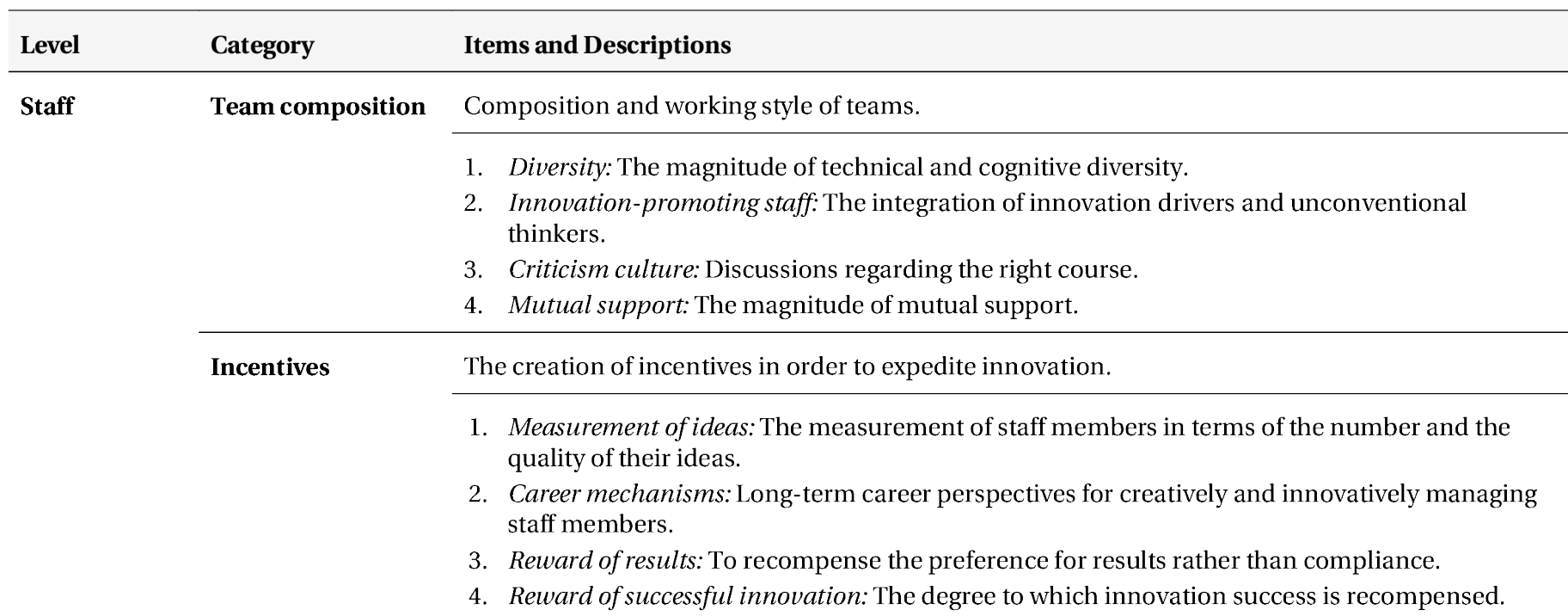

\section{Environment Communication Innovation-promoting communication.}

1. Lateral communication: Cross-divisional, lateral communication.

2. Internal informal networks: The formation of informal networks.

3. External relationships: The forming of external relationships.

4. Meeting culture: The magnitude to which meetings serve the development of new ideas.

\begin{tabular}{l} 
Risk culture Readiness to take risks. \\
\cline { 2 - 3 } 1. Mistake acceptance: The acceptance of mistakes. \\
2. Readiness to learn: The readiness to learn from mistakes. \\
3. Mistake quality: The distinction between different types of mistakes. \\
4. Unofficial projects: The frequency of unofficial innovation projects. \\
5. Experimental readiness: The magnitude to which experiments are carried out.
\end{tabular}

Working climate The personally perceived climate in the work environment.

1. Motivated environment: The extent to which colleagues are motivated.

2. Informal contact: Informal contact with one another.

3. Openness to problems: Positive setting in the face of problems and difficulties.

4. Perceived dynamism: The perceived degree of dynamism. 


\section{Strengthening Innovation Capacity through Different Types of Innovation Cultures}

\section{Jens-Uwe Meyer}

Table 2. The four innovation types revealed through factor analysis

\begin{tabular}{|c|c|c|c|c|}
\hline Innovation Type & $\begin{array}{c}\text { Organization } \\
\text { Level }\end{array}$ & $\begin{array}{l}\text { Management } \\
\text { Level }\end{array}$ & $\begin{array}{l}\text { Staff } \\
\text { Level }\end{array}$ & $\begin{array}{c}\text { Environment } \\
\text { Level }\end{array}$ \\
\hline $\begin{array}{l}\text { Mean value of all } \\
\text { interviewees }\end{array}$ & 1.0 & 1.1 & 0.9 & 0.6 \\
\hline Standard divergence & \pm 2.1 & \pm 2.0 & \pm 2.0 & \pm 2.1 \\
\hline Type 1 & 2.0 & 1.9 & 1.9 & 1.6 \\
\hline Standard divergence & \pm 2.4 & \pm 2.3 & \pm 2.4 & \pm 2.5 \\
\hline Type 2 & 1.5 & 1.2 & 1.0 & 0.7 \\
\hline Standard divergence & \pm 1.9 & \pm 1.9 & \pm 1.6 & \pm 2.0 \\
\hline Type 3 & 0.7 & 0.8 & 0.7 & 0.1 \\
\hline Standard divergence & \pm 1.9 & \pm 1.9 & \pm 1.9 & \pm 2.0 \\
\hline Type 4 & 0.0 & 0.5 & 0.4 & 0.0 \\
\hline Standard divergence & \pm 1.9 & \pm 1.9 & \pm 1.8 & \pm 1.8 \\
\hline
\end{tabular}

1. Innovation Type 1 ( $21 \%$ of the interviewees) is characterized by clear evaluation tendencies as regards the features that strongly foster creativity: for all 10 items, statements that represent a culture that fosters organizational creativity achieved high values.

2. Innovation Type 2 (26\% of the interviewees) ranks an average of 0.7 points lower than the first innovation type. Overall, the values fostering creativity are therefore assigned a lower, albeit not homogeneous, level. Of the 10 different categories, strategy, values, management styles, and team composition achieve higher values than the other categories.

3. For Innovation Type 3 (36\% of the interviewees), the mean values on the evaluation scale are an average of 0.4 points lower than Innovation Type 2 and 1.1 points lower than Innovation Type 1. The evaluation level for the categories of strategy, values, management structures, team composition, and incentives is largely homogeneous.
4. Innovation Type 4 (16\% of the interviewees) differs in all categories by 0.4 points from Innovation Type 3 , by 0.8 points from Type 2 , and by 1.5 points from Type 1 . The categories of strategy, values, management structures, resources, incentives, communication, risk culture, and working climate are characterized by a largely homogeneous evaluation level on the lowest level.

The innovation aspiration (Figure 2) is valued at an average of $1.6( \pm 2.6)$ for Innovation Type 1, but with Innovation Type 4 , it is valued at $0.9( \pm 1.8)$. Whereas Innovation Type 1 achieves high values with the courage for radical ideas $(1.6 \pm 2.5)$, the survey respondents who are assigned to the Innovation Type 4 see danger within radical ideas $(0.4 \pm 2.0)$.

Two questions of the survey were directly aimed at determining the degree of innovation the respondent aspires to achieve and the respondent's attitude to radical ideas. When comparing the values achieved by the different innovation types for both questions, a correla- 


\section{Strengthening Innovation Capacity through Different Types of Innovation Cultures} Jens-Uwe Meyer

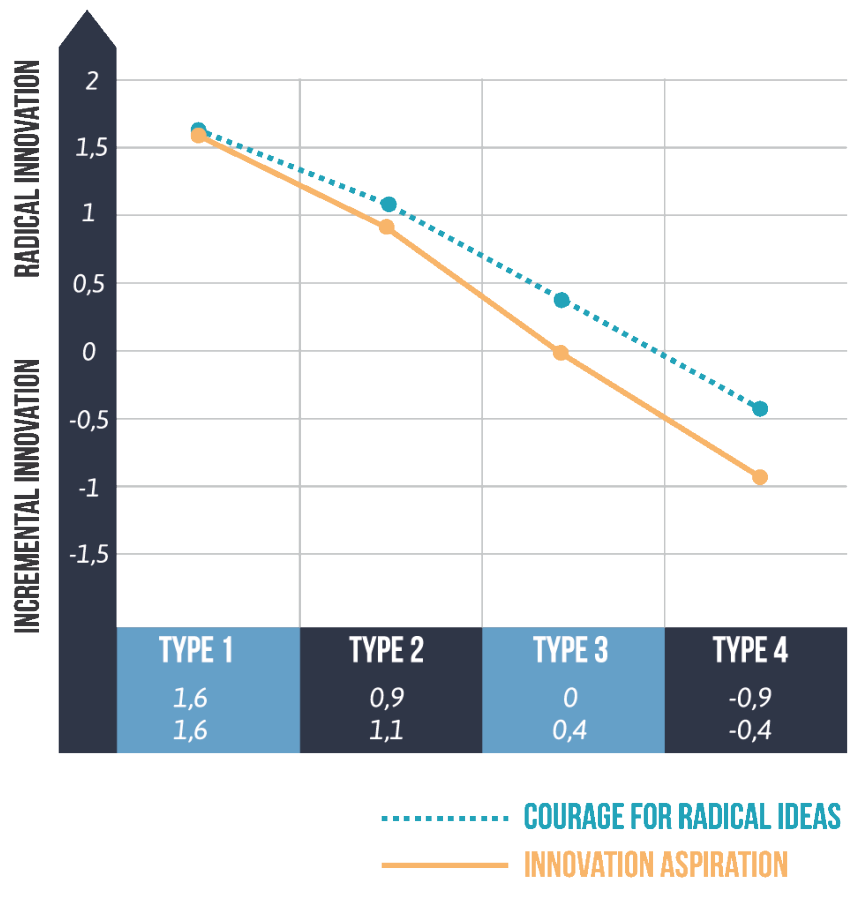

Figure 2. Continuous decrease in the targeted innovation degree

tion becomes apparent: the aim to establish groundbreaking new products on the market and the courage to adopt radical ideas decline steadily. Although Innovation Type 1 evaluates the aim to be the first to establish ground-breaking new products on the market with an average of $1.6( \pm 2.6)$, Innovation Type 4 shows a clear tendency towards incremental innovations and improvements $(-0.9 \pm 1.8)$. Whereas Innovation Type 1 achieves high values with the courage for radical ideas $(1.6 \pm 2.5)$, respondents that are assigned to the Innovation Type 4 see a danger within radical ideas $(0.4 \pm 2.0)$.

\section{Discussion}

The types of innovation cultures were assigned names according to their defining characteristics:

1. Innovation Culture Type 1 is designated as "the Proactive Innovator". Proactive Innovators are entirely oriented toward innovation and can expedite more far-reaching innovations can develop innovations faster than the other innovation types.

2. Innovation Type 2 is designated as "the Strategic Innovator". Through the concentration on the organization level, Strategic Innovators can implement effectively. Through the strong top-down compon- ent, they may adapt themselves more slowly to changed market circumstances than Proactive Innovators.

3. Innovation Type 3 is designated as "the Innovative Optimizer" due to the middle values in all categories. The Innovative Optimizer is oriented toward advancing incremental innovations.

4. Innovation Type 4 is designated as "the Operational Innovator" due to the below-average visionary orientation. This type is rather aligned toward the operational business.

\section{Confirmation of the hypotheses}

The culture of the companies that strive for a high degree of innovation differs significantly from those that aspire toward a lower degree of innovation. The perception that an organization's innovative capacity is only either low or high lacks dimension and is therefore limiting. In order to enable an organization's leadership to manage innovation in highly dynamic markets, it seems to be much more effective to think of suitable degrees of organizational creativity in relation to the specific innovation goals of a company. It can therefore be concluded that the idea that there is a consistent and clearly defined mechanism with which the management can positively impact the innovative capacity through organizational creativity does not sufficiently cover the many dimensions and variables of innovation itself.

\section{Conclusion}

The results of this research are of great practical relevance to the managers of companies. The innovation types developed in this research should enable managers to understand which mechanisms can be activated in different intensities to achieve defined innovation goals. The results should shift the focus in innovation management from the procedural consideration to the establishment of management models that envision company units with varying degrees of organizational creativity.

However, a limitation of this paper is the relatively small sample. One response per company does of course not properly describe the culture of that company. It is recommended to expand the sample and using a more complex process of investigation that covers statistically several management layers within the company. Moreover, future investigations on the subject of innovation should focus on the gradations of organiza- 


\section{Strengthening Innovation Capacity through Different Types of Innovation Cultures} Jens-Uwe Meyer

tional creativity. The different degrees are insufficiently investigated in the literature.

For future research, it is encouraged that surveys similar to that conducted here are repeated - possibly with a higher number of participants. It would be a significant gain in knowledge to discover the extent to which more types of innovation can be defined. Due to the relatively low number of cases in this first research (200 interviewees), four innovation types naturally demonstrate a simplification.

In the meantime, on the basis of this preliminary study, a web-based analysis tool has been developed in German, and an English version will be available in 2015. This tool, which is called Innolytics (innolytics.de) - from "innovation analytics " - helps researchers and managers to measure, analyze, and continuously develop their own innovation capacity. For this purpose, the items discussed in this paper are converted into questions for different management levels and areas of expertise. This tool should help to enable the management of companies to identify and activate those factors that most efficiently improve the innovation capacity of different units. Given that different areas of expertise and business units within companies are usually subjected to different demands for innovation, Innolytics should help to enable the management to establish different innovation cultures in different divisions and business units.

\section{Acknowledgements}

An earlier version of this paper was presented at the first ISPIM Americas Innovation Forum in Montreal, Canada, on October 5-8, 2014. The International Society for Professional Innovation Management (ISPIM; ispim.org) is a network of researchers, industrialists, consultants, and public bodies who share an interest in innovation management.

\section{About the Author}

Jens-Uwe Meyer is Managing Director of Innolytics $\mathrm{GmbH}$, a German consulting company that specializes in analyzing the innovation capacities and cultures of companies. He is author of eight books and numerous articles on the subject of innovation, and he is tutor for the Master's of Management and Innovation program at the Steinbeis SMI Berlin. He holds a doctorate degree in Business Sciences from the HHL Leipzig Graduate School of Management, and he holds an MBA from Steinbeis University in Berlin. In his dissertation, he focused on the topic of enhancing innovation capacity within corporations by establishing different cultures of innovation and reducing innovation barriers.

\section{References}

Ahmed, P. K. 1998. Culture and Climate for Innovation. European Journal of Innovation Management, 1(1): 30-42. http://dx.doi.org/10.1108/14601069810199131

Amabile, T. M. 1996. Creativity and Innovation in Organizations (Note: 9-396-239). Boston: Harvard Business School Publications.

Amabile, T. M. 1998. How To Kill Creativity. Harvard Business Review, 76(5): 77-87.

Amabile, T. M., Conti, R. Coon, H. Lazenby, J., \& Herron, M. 1996. Assessing the Work Environment for Creativity. Academy of Management Journal, 39(5): 1154-1184. http://dx.doi.org/10.2307/256995

Anderson, N. R., \& West, M. A. 1998. Measuring Climate for Work Group Innovation: Development and Validation of the Team Climate Inventory. Journal of Organizational Behavior, 19(3): 235-258.

http://dx.doi.org/10.1002/(SICI)1099-1379(199805)19:3<235::AIDJOB837>3.0.CO;2-C

Barron, F., \& Harrington, D. M. 1981. Creativity, Intelligence and Personality. Annual Review of Psychology, 32: 439-476. http://dx.doi.org/10.1146/annurev.ps.32.020181.002255

Basadur, M. 1987. Needed Research in Creativity for Business and Industry Applications. In S. G. Isaksen (Ed.), Frontiers of Creativity Research: Beyond the Basics. Buffalo, NY: Bearly Ltd.

Benner, M. J., \& Tushman, M. 2002. Process Management and Technological Innovation: A Longitudinal Study of the Photography and Paint Industries. Administrative Science Quarterly, 47(4): 676-706.

http://dx.doi.org/10.2307/3094913

Buzan, T. 2001. The Power of Creative Intelligence. London: Thorsons.

Cabra, J. F., Talbot, R. J. , \& Joniak, A. J.. 2005. Exploratory Study of Creative Climate: A Case From Selected Colombian Companies and its Implication on Organizational Development. Cuadernos di Administración, 18(29): 53-86. 


\section{Strengthening Innovation Capacity through Different Types of Innovation Cultures}

\section{Jens-Uwe Meyer}

Carr-Ruffino, N. 2001. Building Innovative Skills: The Creative Intelligence Model. Boston: Pearson Custom Publishing.

Cooper, R. G., \& Kleinschmidt, E. J. 1996. Winning Business in Product Development: The Critical Success Factors. ResearchTechnology Management, 39(4) 18-29.

Cooper, R. J., \& Kleinschmidt, E. J.. 2001. Stage-Gate Process for New Product Success. Brøndby, Denmark: Innovation Management U3.

Cooper, R. G. 1986. Winning at New Products. Boston: AddisonWesley.

Cooper, R. G. 1988. The New Product Process: A Decision Guide for Management. Journal of Product Innovation Management, 3(3): 238-255.

http://dx.doi.org/10.1080/0267257X.1988.9964044

Cooper, R. G. 1994. Perspective Third-Generation New Product Processes. Journal of Product Innovation Management, 11(1): 3-14. http://dx.doi.org/10.1016/0737-6782(94)90115-5

Cooper, R. G. 2014. What's Next?: After Stage-Gate. ResearchTechnology Management, 57(1): 20-31.

http://dx.doi.org/10.5437/08956308X5606963

Csikszentmihalyi, M. A. 2006. Systems Perspective on Creativity. In J. Henry (Ed.), Creative Management and Development: 313-335. London: Sage Publications.

Dewey, J., Kallen, H. M., Tufts, J. H., Moore, A. W., Brown, H. C., Mead, G. H., Bode, B. H., \& Stuart, H. W. 2011. Creative Intelligence. Calgary, $\mathrm{AB}$ : Teophania Publishing.

Dobni, C. 2008. Measuring Innovation Cultures in Organizations: The Development of a Generalized Innovation Culture Construct Using Exploratory Factor Analysis. European Journal of Innovation Management, 11(4): 539-559.

http://dx.doi.org/10.1108/14601060810911156

Drucker, P. F. 1985. The Discipline of Innovation. Harvard Business Review, 63(3): 67-72.

Ekvall, G., \& Tångeberg-Andersson, Y. 1986. Working Climate and Creativity. A Study of an Innovative Newspaper Office. Journal of Creative Behavior, 20(3) 215-225.

http://dx.doi.org/10.1002/j.2162-6057.1986.tb00438.x

Ekvall, G. 1996. Organizational Climate for Creativity and Innovation. European Journal of Work and Organizational Psychology, (5)1: 105-123.

http://dx.doi.org/10.1080/13594329608414845

Ekvall, G. 2006. Organizational Conditions and Levels of Creativity. In J. Henry (Ed.), Creative Management and Development: 195-205. London: Sage Publications.

Farson, R., \& Keyes, R. 2002. The Failure Tolerant Leader. Harvard Business Review, 80(8): 95-104.

Feist, G. J. 2010. The Function of Personality in Creativity. In J. Kaufman \& R. J. Sternberg (Eds.), The Cambridge Handbook of Creativity: 113-130. New York: Cambridge University Press.

Hill, A., Tan, A., \& Kikichi, A. 2008. International High School Students' Perceived Creativity Self-Efficacy. Korean Journal of Thinking and Problem Solving, 18(1): 105-115.

Högman, U., \& Johannesson, H. 2013. Applying Stage Gate Processes to Technology Development - Experience From Six HardwareOriented Companies. Journal of Engineering and Technology Management, 30(3): 264-287.

http://dx.doi.org/10.1016/j.jengtecman.2013.05.002
Junarsin, E. 2009. Managing Discontinuous Innovation. International Management Review, 2(5): 10-18.

Kaufman, J. C., \& Sternberg, R. J. 2006. The International Handbook of Creativity. New York: Cambridge University Press.

Khandwalla, P. N., \& Mehta, K. 2004. Designs of Corporate Creativity. Vikalpa, 29(1): 13-28.

Kirton, M. J. 1989. A Theory of Cognitive Style. In M. Kirton (Ed.), Adaptors and Innovators: Styles of Creativity and Problem Solving: 1-33. New York: Routledge.

Kozbelt, A. 2008. Gombrich, Galenson, and Beyond: Integrating Case Study and Typological Frameworks in the Study of Creative Individuals. Empirical Studies of the Arts, 26(1): 51-68. http://dx.doi.org/10.2190/EM.26.1.e

Kozbelt, A., Beghetto, R. A., \& Runco, M. A. 2010. Theories of Creativity. In J. Kaufman \& R. J. Sternberg (Eds.), The Cambridge Handbook of Creativity: 20-47. New York: Cambridge University Press.

Kromrey, H. 2002. Empirische Sozialforschung. Modelle und Methoden der Datenerhebung und Datenauswertung. 10. Aufl. Stuttgart, Berlin, Köln: UTB.

Leifer, R., McDermott, C. M., O'Connor, G. C., Peters, L. S., Rice, M., \& Veryzer, Jr., R. W. 2000. Radical Innovation: How Mature Companies Can Outsmart Startups. Boston: Harvard Business School Press Books.

Lin, C. Y.-Y., \& Liu, F.-C. 2012. A Cross-Level Analysis of Organizational Creativity Climate and Perceived Innovation: The Mediating Effect of Work Motivation. European Journal of Innovation Management, 15(1): 55-76. http://dx.doi.org/10.1108/14601061211192834

Martins, E. C., \& Terblanche, F. 2003. Building Organizational Culture That Stimulates Creativity and Innovation. European Journal of Innovation Management, 6(1): 64-74. http://dx.doi.org/10.1108/14601060310456337

Martinsen, Ø. 1995. Cognitive Styles and Experience in Solving Insight Problems: Replication and Extension. Creativity Research Journal, 8(3): 291-298. http://dx.doi.org/10.1207/s15326934crj0803_8

Moosbrugger, H., \& Kelava, A. 2012. Testtheorie und Fragebogenkonstruktion. Berlin: Springer.

Moosbrugger, H., \& Schermelleh-Engel, K. 2012. Exploratorische EFA und Konfirmatorische Faktorenanalyse CFA. In H. Moosbrugger \& A. Kelava (Eds.), Testtheorie und Fragebogenkonstruktion. Berlin: Springer.

Naranjo, J., Valle, R. S., \& Jiménez, D. J. 2010. Organizational Culture as Determinant of Product Innovation. European Journal of Innovation Management, 13(4): 466-480. http://dx.doi.org/10.1108/14601061011086294

Noack, M. 2007. Faktorenanalyse. Institut für Soziologie, Universität Duisburg-Essen.

Prabhu, V., Sutton, C., \& Sauer, W. 2008. Creativity and Certain Personality Traits: Understanding the Mediating Effect of Intrinsic Motivation. Creativity Research Journal, 20(1): 53-66. http://dx.doi.org/10.1080/10400410701841955

Puccio, G. J., \& Cabra, J. F. 2010. Organizational Creativity - A Systems Approach. In J. Kaufman \& R. J. Sternberg (Eds.), The Cambridge Handbook of Creativity: 145-173. New York: Cambridge University Press. 


\section{Strengthening Innovation Capacity through Different Types of Innovation Cultures}

\section{Jens-Uwe Meyer}

Rammer, C., Aschhoff, B., Crass, D., Doherr, T., Hud, M., \& Köhler, C., Peters., B., Schubert, T, \& Schwiebacher, F. 2011. Indikatorenbericht zur Innovationserhebung 2011, Zentrum für Europäische Wirtschaftsförderung im Auftrag des Bundesministerium für Bildung und Forschung.

Rickards, T., \& Bessant, J. 1980. The Creativity Audit: Introduction of a New Research Measure During Programmes for Facilitating Organizational Change. R\&D Management, 10(2): 67-75. http://dx.doi.org/10.1111/j.1467-9310.1980.tb00014.x

Rickards, T. 1996. The Management of Innovation: Recasting the Role of Creativity. European Journal of Work and Organizational Psychology, 5(1): 13-27. http://dx.doi.org/10.1080/13594329608414835

Robinson, A. G., \& Stern, S. 1997. Corporate Creativity - How Innovation And Improvement Actually Happens. San Francisco: Berrett-Koehler Publishers.

Roth, G. 2001. Fühlen, Denken, Handeln. Wie das Gehirn unser Verhalten steuert. Frankfurt: Suhrkamp.

Runco, M. A., \& Albert, R. S. 2010. Creativity Research: A Historical View. In J. Kaufman \& R. J. Sternberg (Eds.), The Cambridge Handbook of Creativity: 3-19. New York: Cambridge University Press.

Siegel, S. M., \& Kaemmerer, W. F. 1978. Measuring the Perceived Support for Innovation in Organizations. Journal of Applied Psychology, 63(5): 553-562.

http://psycnet.apa.org/doi/10.1037/0021-9010.63.5.553
Soriano Alencar, E. M. L. de, \& Bruno-Faria, M. D. F. 1997. Characteristics of an Organizational Environment Which Stimulates and Inhibits Creativity. Journal of Creative Behavior, 31(4): 271-281.

http://dx.doi.org/10.1002/j.2162-6057.1997.tb00799.x

Sternberg, R. J. 1996. Successful Intelligence: How Practical and Creative Intelligence Determine Success in Life. New York: Simon and Schuster.

Tushman, M. L., \& O'Reilly III, C. A. 1996. Ambidextrous Organizations: Managing Evolutionary and Revolutionary Change. California Management Review, 38(4): 8-30. http://www.jstor.org/stable/41165852

Unsworth, K. L., \& Clegg, C. W. 2010. Why Do Employees Undertake Creative Action? Journal of Occupational and Organizational Psychology, 83(1): 77-99.

http://dx.doi.org/10.1348/096317908X398377

Van Gundy, A. Organizational Creativity and Innovation. 1987. In S. G. Isaksen (Ed.), Frontiers of Creativity Research: Beyond the Basics: 358-379. Buffalo, NY: Bearly Ltd.

von Stamm, B. 2005. Managing Innovation, Design and Creativity. Hoboken, NJ: John Wiley and Sons.

Woodman, R. W., Sawyer, J. E., \& Griffin, R. W. 1993. Towards a Theory of Organizational Creativity. Academy of Management Review, 18(2): 293-321. http://dx.doi.org/10.5465/AMR.1993.3997517

Zhou, J., \& Shalley, C. E. 2008. Handbook of Organizational Creativity. New York: Lawrence Erlbaum Associates. 